\title{
Relationships between the abundance of bacteria and other biota and the hydrographic variability in the Ría de Vigo, Spain
}

\author{
M. K. Zdanowski ${ }^{1}$, F. G. Figueiras ${ }^{2, *}$ \\ ${ }^{1}$ Department of Antarctic Biology, Polish Academy of Sciences, 02-141 Warsaw, Ustrzycka 10, Poland \\ ${ }^{2}$ Instituto de Investigaciones Marinas, CSIC, Eduardo Cabello 6, E-36208 Vigo, Spain
}

\begin{abstract}
Hydrographic variability driven by changes in wind speed and direction and by meteorological parameters, such as incoming solar radiation, fluvial discharges, and temperature, affects biological standing stocks (e.g. of bacteria) in the marine environment. We studied the effects of such parameters in the Ria de Vigo (Galicia, Spain), between October 1990 and August 1991, where downwelling in winter results from predominantly poleward winds, whilst in summer upwelling is driven by winds travelling towards the equator Total bacterial abundance was strongly affected by physical factors in the Ria de Vigo. Almost $60^{\prime \prime}$ of the variance in bacterial abundance in the surface layer could be explained by an equation relating $\log T C$ [log(total count of heterotrophic bacterioplankton)] to incoming solar radiation, water temperature, run-off and coastal upwelling, where solar radiation, water temperature and moderate upwelling are all positive terms, while run-off and strong upwelling act negatıvely. Consideration of biological variables such chlorophyll, ciliates and heterotrophic flagellates did not further explain the variance. Physical factors, however, only accounted for $40 \%$ of the total variance in bacterial abundance at the bottom of the photic layer. The inclusion of biological variables in the regression equations increased the explained variance to $55 \%$; chlorophyll was the most important of these variables and was positively related to $\log \mathrm{TC}$. This indicates that bacterial populations in the surface layer are mainly controlled by physical factors with a weak phytoplankton influence; however, a stronger coupling between primary production and bacterial growth must exist at the bottom of the photic layer. Physical variables also explained 60 to $65 \%$ of the variance in cultivable spore-forming saprophytic bacteria, but, in contrast to effects on total bacterial numbers, run-off had a positive effect while moderate upwelling had a negative influence on spore-forming numbers. This suggests that terrestrial run-off has some ecological importance through the enrichment of nearshore bactenal populations with cells of terrestrial origin.
\end{abstract}

KEY WORDS: Upwelling - Run-off - Bacteria - Phytoplankton Protozooplankton - Hydrographic variables Estuarine ecosystem Ría de Vigo

\section{INTRODUCTION}

Ría de Vigo (Spain) is a typical large maritime Galician bay covering $176 \mathrm{~km}^{2}$ and containing $3317 \times 10^{6}$ $\mathrm{m}^{3}$ of water (Fraga \& Margalef 1979). It attains a depth of $40 \mathrm{~m}$ in the central part of its U-shaped cross section (Fig. 1), the site chosen for regular bacteriological sampling (Stn 3b). As with the other 3 rías in this area

\footnotetext{
•Addressee for correspondence. E-mail:paco@iim.csic.es
}

(Muros, Arousa and Pontevedra), the bay penetrates the Galician coast in a northeasterly direction, in this case to a distance of $33 \mathrm{~km}$. The bay opens widely to the west, and its hydrology is influenced by both Atlantic Ocean upwelling (mainly in summer) and by freshwater run-off as a function of the rainfall in the drainage basin (mainly in winter). The mouth of the ría is partially closed by the Cies Islands, and therefore opens to the ocean through 2 'channels', the southern one of which is $5 \mathrm{~km}$ wide and $67 \mathrm{~m}$ deep and the northern some $2.5 \mathrm{~km}$ wide and $23 \mathrm{~m}$ deep. In contrast 


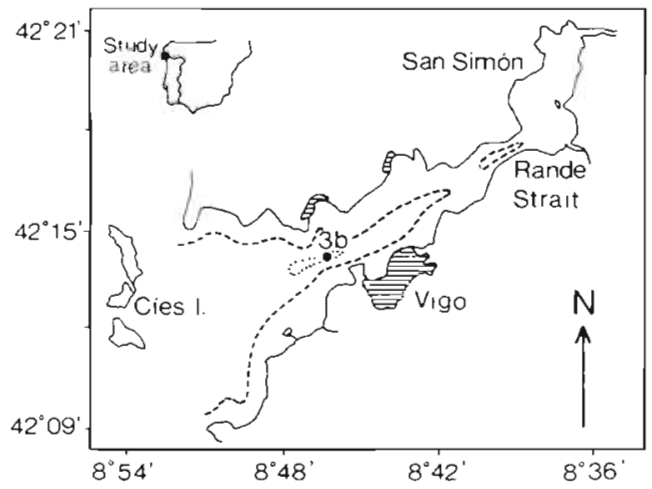

Fig. 1 Ría de Vigo (northwest corner of Iberian peninsula) showing the sampling station (3b). Dashed and dotted lines indicate the location of the 20 and $40 \mathrm{~m}$ isobaths, respectively

to the main body of the Ría de Vigo, the bay's inner reaches (San Simón Inlet) are partially separated from the main body and protected from direct oceanic influence by a narrow channel (Rande Strait) of $700 \mathrm{~m}$ width.

The nydroiogical characteristics of the Ría de vigyo are well documented (Fraga \& Margalef 1979, Prego et al. 1990, Prego \& Fraga 1992, Rios et al. 1992, AlvarezSalgado et al. 1993, Figueiras et al. 1994), as are its physico-chemical characteristics (Prego 1990). In general there are 2 layers of water in the Ría de Vigo: the lower and more saline layer enters as subsurface oceanic water that compensates for the less saline water flowing out at the surface. In summer, prevailing coastal northerly winds promote coastal upwelling which introduces biogenic salts into the Ría and forces an outflow of surface waters. These upwelled waters migrate from the ocean across the bottom, ascending and infiltrating the very stable upper layer, and in so doing provide it with a steady supply of nutrients. During spring, when vertical stratification is not as strong as in summer, upwelled water penetrates the upper layer, mixing the water of the 2 layers. Downwelling also produces an homogenous water column, but in this case by reversing the circulation. Surface coastal water is advected into the Ría and pushed down in its interior. In winter, a classical positive estuarine circulation develops, driven by the less saline outgoing water derived from terrestrial run-off (Fraga \& Margalef 1979, Prego et al. 1990). Consequently, it is expected that bacteria from this system will be under strong hydrological, meteorological and biological pressures.

Due to the unique ability of heterotrophic bacteria to utilise soluble compounds in very low concentrations (Morita 1984), they are a basic component of the marine food web. Transferring dissolved organic matter (DOM) to their own cells, they initiate energy flow through bacterivores (Fuhrman \& McManus 1984, Ras- soulzadegan \& Sheldon 1986, Garrison \& Gowing 1993) to higher trophic levels (Williams 1981, Azam et al. 1983, Ducklow 1983). Moreover, by converting particulate organic matter (POM) to both soluble and detrital forms (Karl \& Knauer 1984, Zdanowski 1988), heterotrophic bacteria play an important role in the regeneration of many types of organic matter in the pelagic zone of oceanic ecosystems.

Galician coastal waters have very high primary and secondary production, and the microbial loop is important in the food web in these waters (Hanson et al. 1986, Blanton et al. 1987, Tenore at al. 1995). Few data exist on bacteria in the Galician rias ecosystems (Fierro et al. 1976a, b. Anonymous 1987) and these are mainly concerned with bacteriological investigations related to pollution, epidemiology, and public hygiene. So far there are no data on the status of bacteria in the trophic structure or on the dependence of bacteria upon seasond cycles in the Galician marine ecosystem. As an initial step, we have commenced bacteriological studies in the Ría de Vigo with the aim of describing aspects of ecological interactions between marine heterotrophic bacteria and other auto- and heterotrophic microorganisms, abiotic components, and hydrological parameters. As it is generally accepted that the primary habitat of most aerobic spore-forming bacteria is the soil (Alexander 1971) and as terrestrial run-off is important in the Ría de Vigo, this fraction of bacteria was also considered.

\section{MATERIAL AND METHODS}

Investigations were conducted between 31 October 1990 and 19 August 1991 at Stn 3b (Fig. 1) in the central part of the Ría de Vigo; this station has been used for regular oceanographic sampling since 1987 . Sampling was conducted between 09:00 and 10:00 h without consideration of tidal state, viz. effects of tide on circulation and mixing; these are negligible when compared with those imposed by upwelling-downwelling cycles and run-off in Galician rías (Figueiras et al. 1994, Rosón et al. 1995). Water samples for bacterial work were collected with an ethanol-rinsed Van Dorn type 5 l plastic bottle from the surface $(0 \mathrm{~m})$, from the middle layer (bottom of the photic layer, characterised by $1 \%$ of total light reaching the surface), and from the bottom layer (about $5 \mathrm{~m}$ above the bottom). The first part of the water in the sampler was discarded by flushing through the tap. Thereafter, sub-samples (ca $100 \mathrm{ml}$ ) were immediately transferred to sterile, opaque, screw-capped glass bottles and maintained at ca $5^{\circ} \mathrm{C}$ until processed in the laboratory, within 2 to $3 \mathrm{~h}$.

The total count (TC) of heterotrophic bacterioplankton was determined (bi-weekly for the surface and 
middle layers, and once a week for the bottom layer) in water samples fixed with formalin $4 \%$ final concentration by epifluorescence microscopy on $0.2 \mu \mathrm{m}$ black Millipore polycarbonate filters, using DAPI (4'6-diamidino-2-phenylindole) (Porter \& Feig 1980). Both total (Cyan) and dividing (CyanD) cyanobacteria were counted in parallel to heterotrophic bacterioplankton, after Davis \& Sieburth (1982). Heterotrophic picoflagellates (HPF) ( $\leq 2 \mu \mathrm{m})$ and nanoflagellates (HNF) (between 2 and $20 \mu \mathrm{m}$ ) were also counted in these same samples (i.e. the DAPI sample). Ciliates (Cil) were counted in samples fixed with Lugol's iodine using an inverted microscope. Cyan, CyanD, HPF, HNF and Cil were determined in the surface and middle layers only.

Heat-resistant spore-forming aerobic bacteria were described in terms of Colony Forming Units (CFUs): $10 \mathrm{ml}$ of water was incubated at $80^{\circ} \mathrm{C}$ for $10 \mathrm{~min}$, then mixed with $10 \mathrm{ml}$ of double-strength Bacto Marine Agar 2216 (ZoBell 1941) and poured into petri dishes (Fenchel \& Hemmingsen 1974). Media were prepared using aged seawater. Water samples were homogenised aseptically immediately before inoculation (Ultra Turrax for $30 \mathrm{~s}$ ) whilst maintained in an ice bath. Plates were incubated in darkness for up to $15 \mathrm{~d}$ at $24^{\circ} \mathrm{C}$.

Temperature (Temp), salinity (Sal), and density (Dens) were determined by CTD casts. The upwelling index for the previous $3 \mathrm{~d}$ plus the sampling day (Upw4) was calculated using geostrophic winds off Cape Finisterre derived from surface pressure (3 times $\mathrm{d}^{-1}$ ) according Bakun (1973). Run-off (Qr4) was calculated following the equation proposed by Ríos et al. (1992), taking into account rainfall over the preceding $3 \mathrm{~d}$ and using a retention coefficient of 0.75 . Mean incoming solar radiation of the preceding $3 \mathrm{~d}$ plus sampling day (Qs4) was estimated by Mosby's formula (Dietrich et al. 1980). Chlorophyll a (chl a) was determined fluorimetrically (Yentsch \& Menzel 1963). Nutrients were determined in an auto-analyser. Nitrate $\left(\mathrm{NO}_{3}\right)$, after reduction to nitrite through a $\mathrm{Cu} / \mathrm{Cd}$ column, was determined according to Hansen \& Grasshoff (1983) modified by Mouriño \& Fraga (1985). Silicate $\left(\mathrm{SiOH}_{4}\right)$ was analysed following Hansen \& Grasshoff (1983). Ammonium $\left(\mathrm{NH}_{4}\right)$ was determined according to Grasshoff \& Johannsen (1972).

\section{RESULTS}

\section{Bacterioplankton (DAPI-TC)}

On the basis of incoming solar radiation (Qs4) the study period was divided into winter (lowest Qs4: November to February), and summer (highest Qs4: March to August) (Fig. 2). Total bacterial counts ranged from $4.9 \times 10^{5}$ to $6.2 \times 10^{6} \mathrm{ml}^{-1}$ for the whole

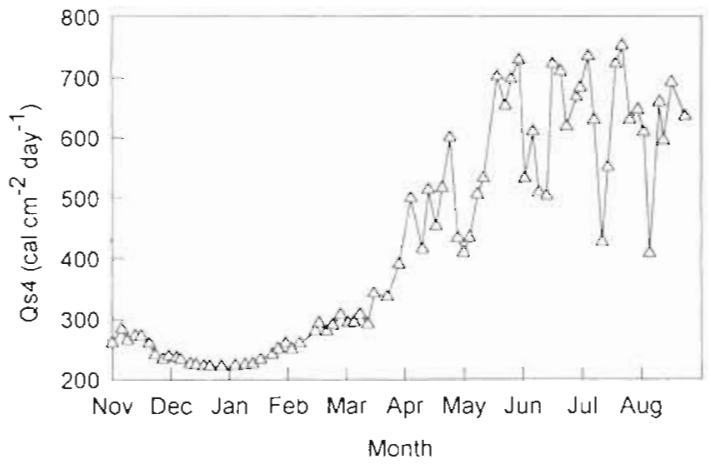

Fig. 2. Seasonal variations in incoming solar radiation (Qs4) in Ría de Vigo. Means from previous 3 d plus sampling day

period (November to August), with minimal values in the winter and maximal values in the summer. Distinct seasonal trends in terms of TC increases were noted at all depths (Fig. 3d), with the greatest increase at the surface (Fig. 3a, d), where the mean value in summer exceeded that in winter by a factor of 2 ; TC in the middle and bottom layers during summer exceeded winter values by only 1.3 and 1.5 times, respectively (Fig. 3 bd). Bacterial numbers decreased with depth. In terms of mean values in the middle and bottom layers, these were 1.6 and 1.8 times lower, respectively, than at the surface.

Considerable fluctuations in TC occurred in each month and at each depth (Fig. 3). Fluctuations were higher in summer than in winter, and were greatest during summer at the surface where the maximum: minimum ratio was 8.7 . The lowest ratio (1.5) was observed during winter in bottom samples.

Hydrological properties of the water column [primarily characterised by 4 parameters: density, temperature, run-off in the drainage basin, and the upwelling index] also fluctuated considerably (Fig. 4). The most dramatic change in density (Fig. 4a) occurred during winter (January) with a steep drop at the surface, from 27.2 (20 December) to 9.4 (11 January), while relatively high values were recorded in the middle layer (26.8 to 23.7). The lowest density values (26) in the bottom layer for the whole period of observations were also recorded during this period. The abrupt change in density was not reflected in temperature (Fig. 4b), indicating that run-off (Fig. 4c) was the factor responsible. These observations are also consistent with the correlation between run-off (i.e. high) in the drainage basin (up to $100 \mathrm{~m}^{3} \mathrm{~s}^{-1}$ ) and the very strong downwelling (to less than $-2000 \mathrm{~m}^{3} \mathrm{~s}^{-1} \mathrm{~km}^{-1}$ of coast) over this period of about 3 wk (Fig, 4c, d). During the development of this first strong downwelling (throughout December and January), TC in each layer decreased (Fig. 3a-c), reaching minimum values in the 3 layers. By the end of 

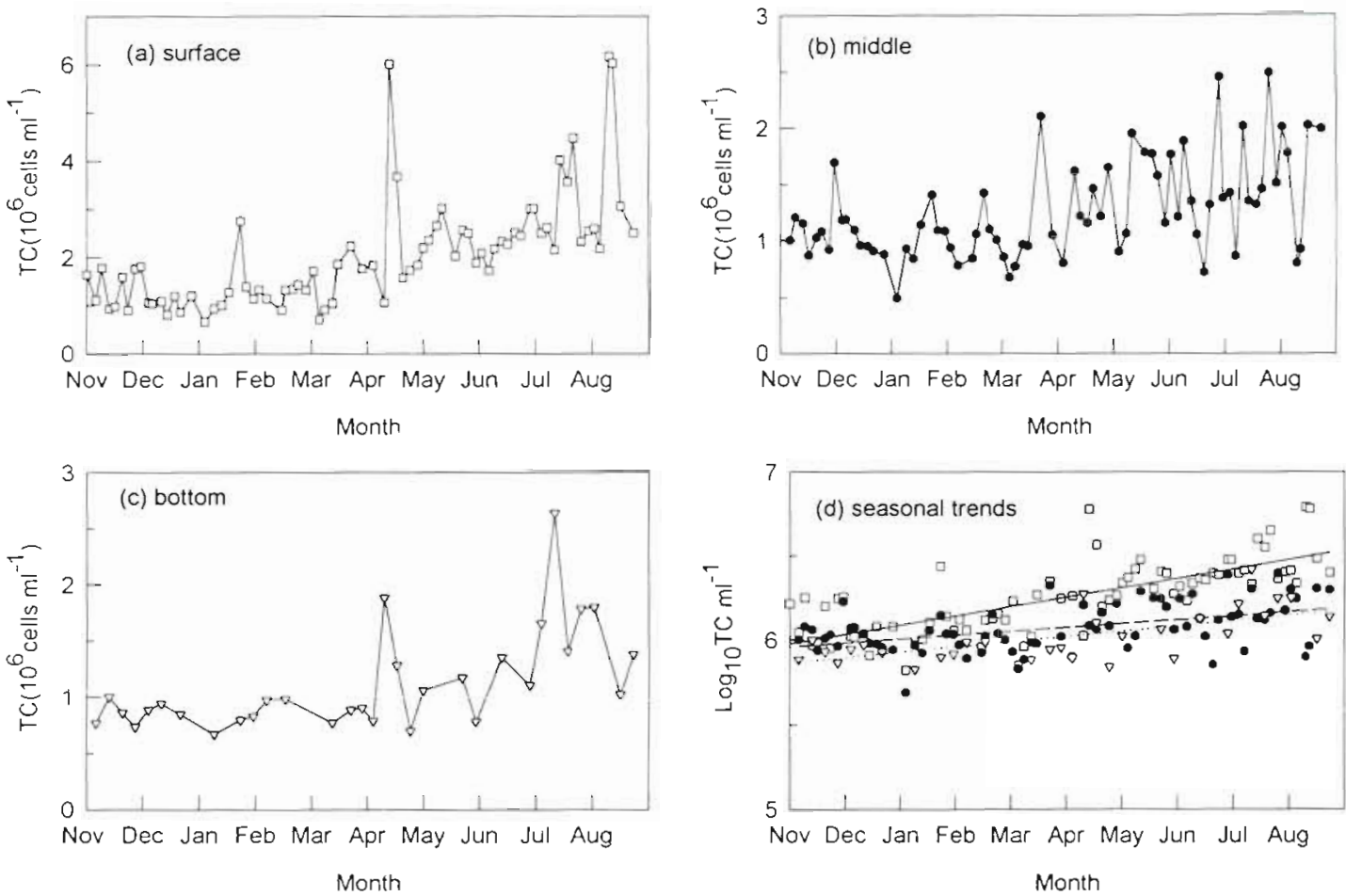

Fig. 3. Total bacterioplankton numbers (DAPI-TC) in the (a) surface, (b) middle (bottom of the photic layer) and (c) bottom layers of Ría de Vigo (Stn 3b) and (d) their seasonal trends, as revealed by the following regression equations: surface ( $\square, \square$, logTC $=5.979+0.001 .9 \cdot$ Julian Day, $\mathrm{r}^{2}=0.54 \cdots, \mathrm{n}=75 ;$ middle $\left(\cdot, \cdots-\cdots, \log \mathrm{TC}=5.959+7.9 \times 10^{-4} \cdots\right.$ Julian Day, $\mathrm{r}^{2}=0.23 \cdots, \mathrm{n}=74$ bottom $(\nabla, \cdots \cdots), \operatorname{logTC}=5.865+0.0011 \cdots$ Julian Day, $r^{2}=0.42 \cdots, n=31, \cdots p<0.001$

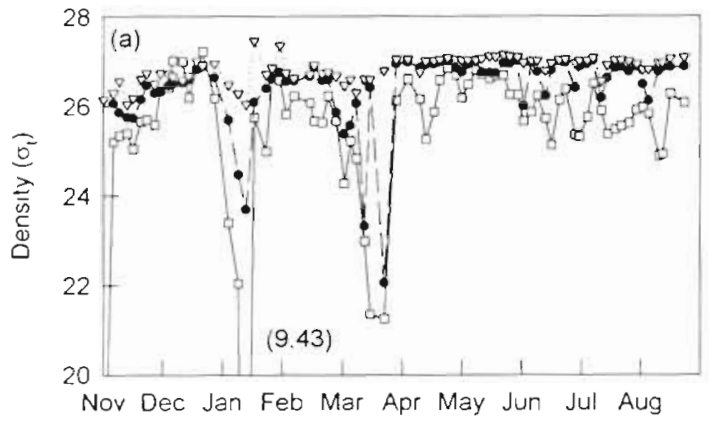

Month

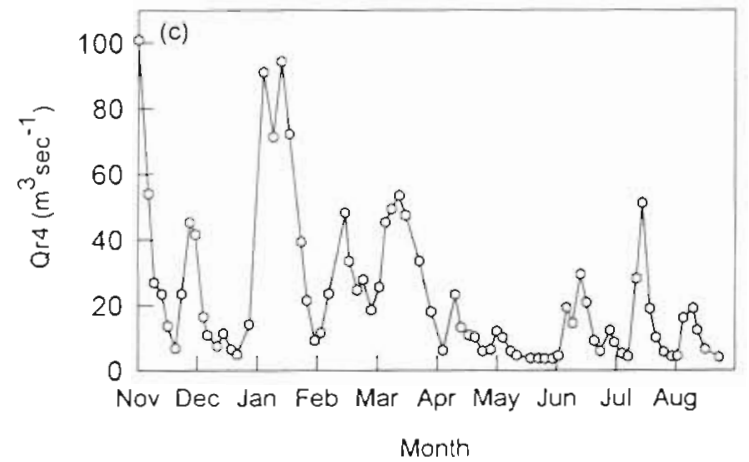

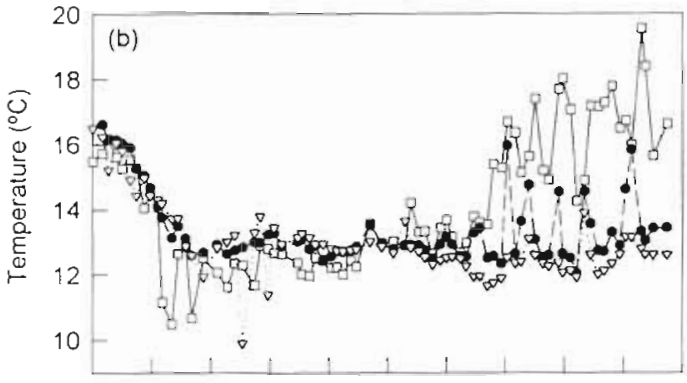

Nov Dec Jan Feb Mar Apr May Jun Jul Aug

Month

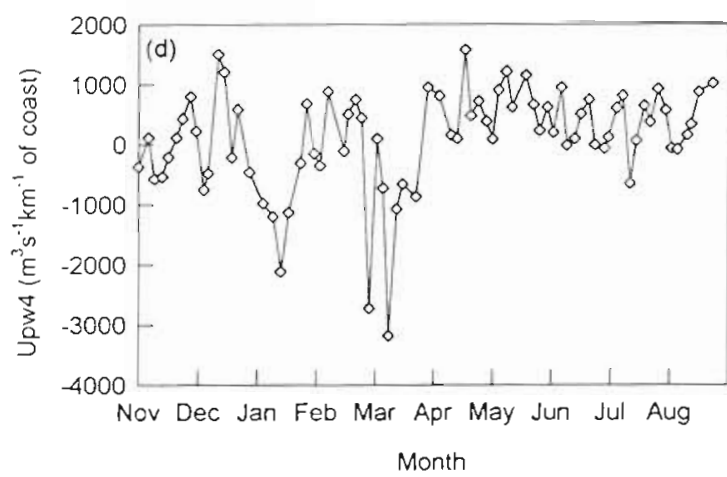

Fig. 4. Seasonal variations in (a) density and (b) temperature in the 3 layers at $\mathrm{Stn} 3 \mathrm{~b}$ ( $\mathrm{\square}$ : surface, $\cdot$ middle, $\nabla$; bottom) and in (c) runoff (Qr4) and (d) upwelling index (Upw4). Qr4 and Upw4 are averaged values from the 3 previous days plus sampling day 
January, coinciding with the decay of these hydrological phenomena and with a downwelling to upwelling transition (Fig. 4d), TC increased at the 3 depths (Fig. $3 a-c)$, reaching high levels considering the winter conditions. In spite of this event there were no significant correlations between $\mathrm{TC}$ and density or between TC and upwelling at any depth during winter (Table 1). A similar situation, although of a lesser order, occurred during the March upwelling-downwellingupwelling transition, when density dropped to 21.2 at the surface (Fig. 4a). From late March, the upwelling index fluctuated mainly within positive values (up to $1586 \mathrm{~m}^{3} \mathrm{~s}^{-1} \mathrm{~km}^{-1}$ of coast in April), with the only exception in July (Fig. 4d), when relatively high run-off in the drainage basin (Fig. 4c) occurred. During summer, as in winter, no significant positive correlation was observed between TC and density at the 3 depths, but a significant positive correlation with upwelling was found at the surface, at the same time that Qr4 negatively correlated with the total bacterial counts at the surface and in the middle layer (Table 1). The high

Table 1. Correlation coefficients $(" p<0.05, \cdots p<0.01, \cdots p<$ $0.001)$ between total bacterial counts (TC) and other hydrographical and biological variables [incoming solar radiation (Qs4), water temperature (Temp), upwelling index (Upw4), run-off (Qr4), water density (Dens), chl a (Chl), cyanobacteria numbers (Cyan), numbers of dividing cyanobacteria (CyanD), heterotrophic picoflagelates (HPF), heterotrophic nanoflagellates (HNF), and ciliates (Cil)] during winter (W) and summer (S) in 3 layers of Ría de Vigo (Stn 3b)

\begin{tabular}{|c|c|c|c|c|}
\hline Variables & Season & Surface & $\begin{array}{c}\text { Middle } \\
\text { (1\% of light) }\end{array}$ & Bottom \\
\hline \multirow[t]{2}{*}{ TC-Qs4 } & W & 0.22 & 0.19 & 0.42 \\
\hline & $\mathrm{S}$ & $0.54 \cdots$ & 0.26 & 0.12 \\
\hline \multirow{2}{*}{ TC-Temp } & W & 0.20 & 0.19 & 0.04 \\
\hline & $\mathrm{S}$ & $0.68 \cdots$ & $0.48^{\cdots} \cdots$ & 0.44 \\
\hline \multirow[t]{2}{*}{ TC-Upw4 } & W & 0.06 & 0.17 & 0.38 \\
\hline & $\mathrm{S}$ & $0.40^{\circ}$ & 0.14 & -0.05 \\
\hline \multirow[t]{2}{*}{ TC-Qr4 } & W & 0.02 & -0.33 & $-0.65^{\circ}$ \\
\hline & $\mathrm{S}$ & $-0.40^{\circ}$ & $-0.35^{\circ}$ & 0.05 \\
\hline \multirow[t]{2}{*}{ TC-Dens } & W & 0.02 & 0.24 & 0.11 \\
\hline & $\mathrm{S}$ & -0.07 & -0.04 & -0.38 \\
\hline \multirow[t]{2}{*}{ TC.Chl } & W & 0.20 & $0.48 \cdot$ & 0.06 \\
\hline & $\mathrm{s}$ & 0.18 & $0.51 \cdots$ & $0.61 \cdots$ \\
\hline \multirow[t]{2}{*}{ TC-Cyan } & W & 0.24 & $0.44^{\circ}$ & \\
\hline & $\mathrm{S}$ & $0.43^{*}$ & 0.15 & \\
\hline \multirow[t]{2}{*}{ TC-CyanD } & W & $0.37^{\circ}$ & $0.46^{\circ}$ & \\
\hline & $\mathrm{S}$ & $0.47^{\circ}$ & 0.04 & \\
\hline \multirow[t]{2}{*}{ TC-HPF } & W & -0.07 & 0.01 & \\
\hline & $\mathrm{S}$ & -0.07 & -0.11 & \\
\hline \multirow[t]{2}{*}{ TC-HNF } & W & 0.01 & 0.02 & \\
\hline & S & 0.10 & 0.17 & \\
\hline \multirow[t]{2}{*}{ TC-Cil } & W & 0.01 & 0.04 & \\
\hline & S & $0.51 \cdots$ & $0.55 \cdots$ & \\
\hline No. of & W & $\mathrm{n}=30$ & $\mathrm{n}=29$ & $\mathrm{n}=12$ \\
\hline samples & $\mathrm{S}$ & $\mathrm{n}=45$ & $\mathrm{n}=44$ & $\mathrm{n}=19$ \\
\hline
\end{tabular}

(surface, middle), and moderate (bottom) positive correlations between $\mathrm{TC}$ and water column temperature in summer (Table 1) should also be noted. On the other hand, as would be expected, Qs4 and surface temperature were strongly positively related $(r=0.69, p<$ $0.001, n=45$ ).

Relationships between bacterial concentrations and other biotic components were also observed. There was a significant positive correlation between TC and chl a (Table 1 ) in the middle layer during winter and summer and in the bottom layer only in summer. The high correlation during summer occurred in spite of strong fluctuations in chl a concentrations (maximum: minimum ratio was 44.2 in summer, compared to 19.2 in winter; Fig. 5). Total cyanobacteria and dividing cyanobacteria correlated with TC at the surface and in
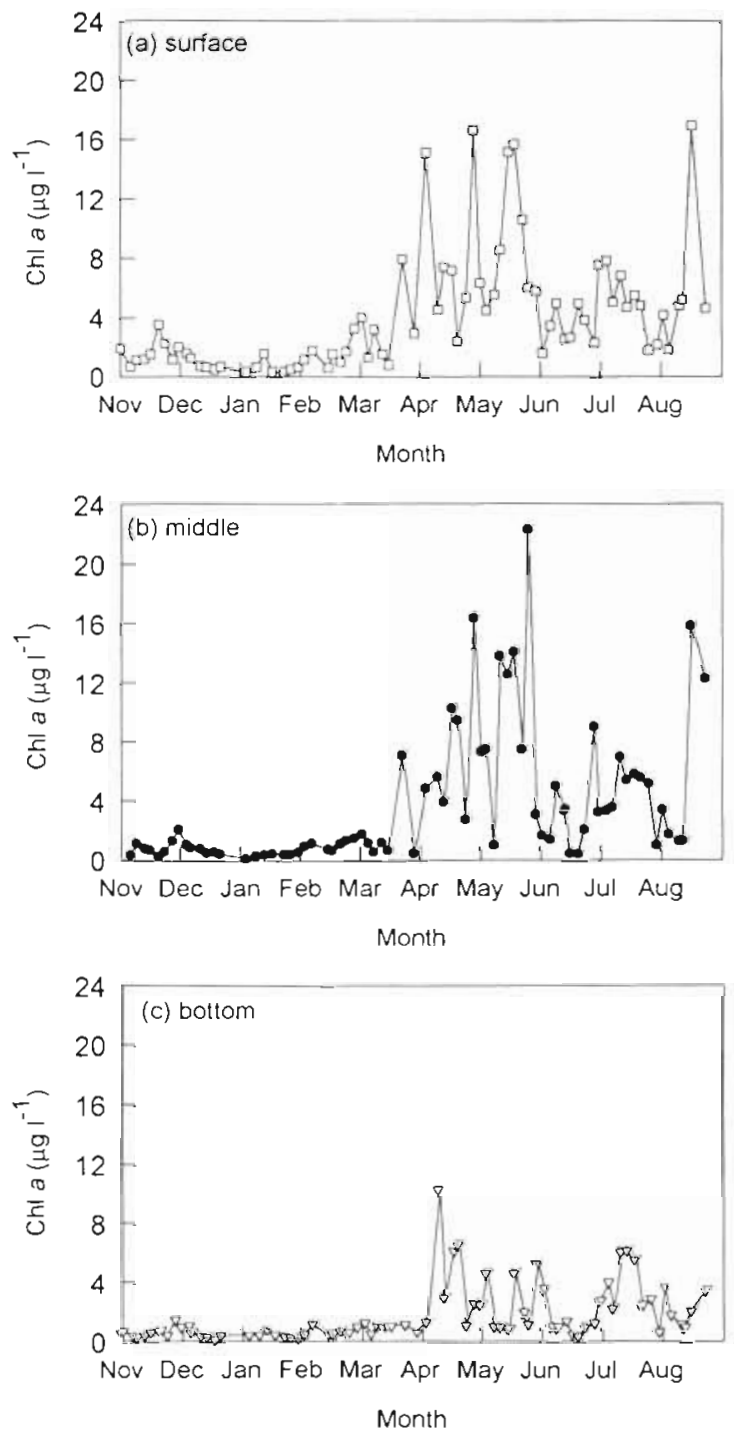

Fig. 5. Seasonal variations in chl a concentration in the (a) surface, (b) middle and (c) bottom layers at Stn 3b 

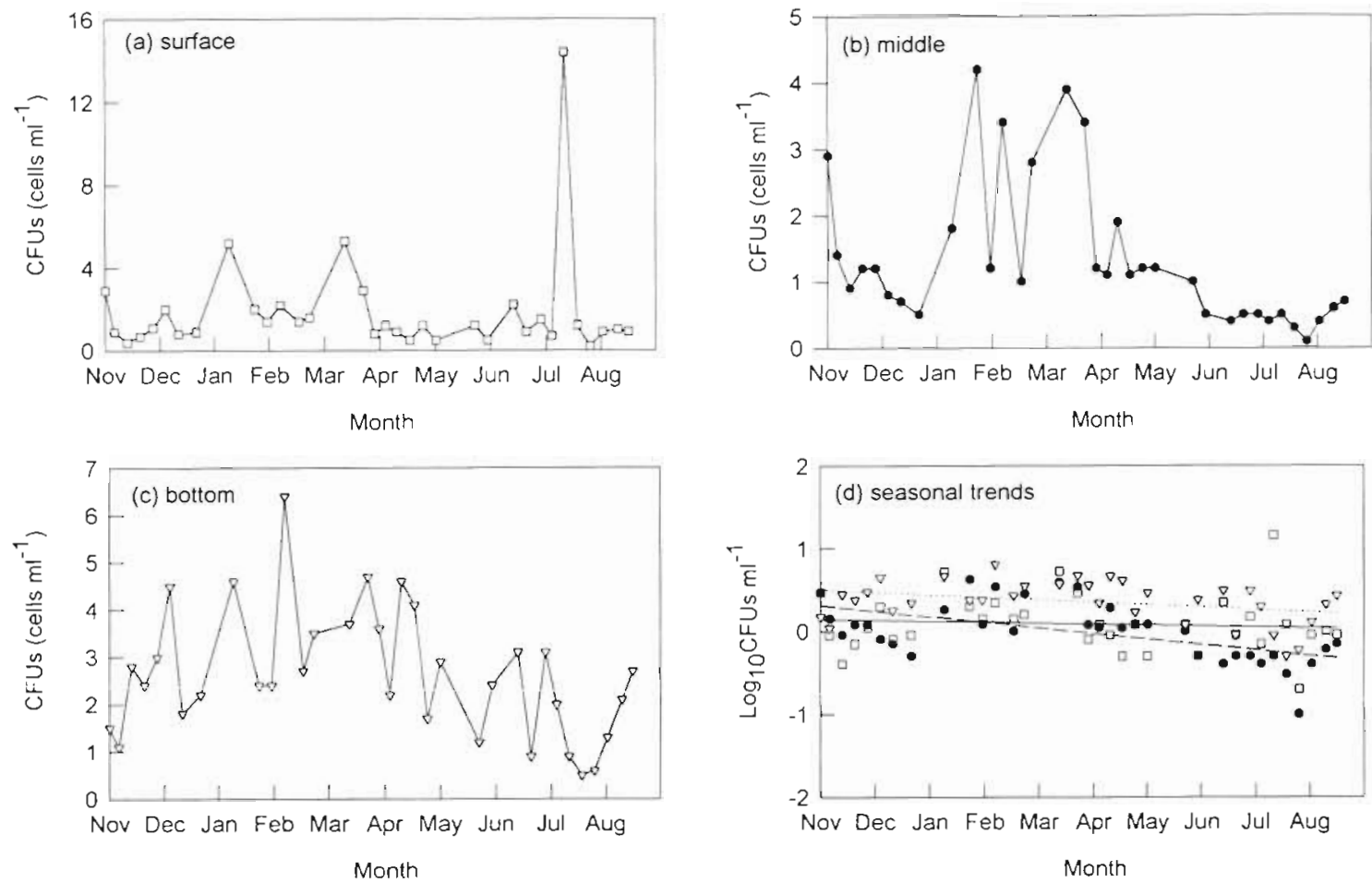

Fig. 6. Number of aerobic spore-forming bacteria (CFUs) in the (a) surface (b) middle and (c) bottom layers of Ría de Vigo (Stn 3b) and (d) their seasonal trends revealed by the following regression equations: surface $(\square,-), \log C F U=0.147-3.94 \times 10^{-4} \mathrm{Julian}$ Day, $\mathrm{r}^{2}=0.01, \mathrm{n}=34 ;$ middle $(\cdot,---)$, $\log \mathrm{CFU}=0.290-2.13 \times 10^{-3} \cdot$ Julian Day, $\mathrm{r}^{2}=0.28 \cdots, \mathrm{n}=34 ;$ bottom $(\nabla, \cdots), \log \mathrm{CFU}=$ $0.5-0.001 \cdot$ Julian Day, $r^{2}=0.12 \cdots, n=34{ }^{*} p<0.05, \cdots p<0.01$

the middle layer. Strong TC versus ciliate correlation was also observed in summer in both layers (Table 1). Conversely, no statistically significant correlations with heterotrophic pico- and nanoflagellates were found (Table 1).

\section{Spore-forming bacteria (CFUs)}

Heat-resistant spore-forming bacteria represented only a very small fraction $(0.0001 \%)$ of the total bacterioplankton (DAPI-TC). They also fluctuated considerably with greatest variations in number at the surface (maximum:minimum ratio $=72$ ) and lowest variations at the bottom (maximum: minimum = 13) (Fig. 6).

Only surface CFU numbers increased slightly over the winter to summer transition (avg $1.68 \mathrm{CFU} \mathrm{ml}^{-1}$ in winter, and $1.94 \mathrm{CFU} \mathrm{ml}^{-1}$ in summer). However, this increase was strongly influenced by the extremely high summer value of $14.4 \mathrm{CFU} \mathrm{ml}^{-1}$ on $8 \mathrm{July}$ (Fig. 6a), when there was relatively high run-off (Fig. 4c). Other summer surface values were actually rather low (avg 1.29 CFU ml-1) and tended to decrease from winter to summer (Fig. 6a). In the middle and bottom layers, a tendency for CFU numbers to decrease from winter to summer was also recorded (Fig. 6b-d).
Table 2. Correlation coefficients $(\cdot p<0.05, \cdots p<0.01, \cdots p<$ 0.001 ) between spore-forming bacterial counts (CFUs) and other hydrological and biological variables in the surface layer of Ría de Vigo (Stn 3b). See Table 1 for abbreviations

\begin{tabular}{|c|c|c|}
\hline Variables & Season & Surface \\
\hline \multirow[t]{2}{*}{ CFUs-Qs4 } & W & -0.21 \\
\hline & $S$ & -0.43 \\
\hline \multirow[t]{2}{*}{ CFUs-Upw4 } & W & -0.40 \\
\hline & $S$ & $-0.74 \cdots$ \\
\hline \multirow[t]{2}{*}{ CFUs-Qr4 } & W & $0.58^{*}$ \\
\hline & $S$ & $0.70 \cdots$ \\
\hline \multirow[t]{2}{*}{ CFUs-Sal } & W & $-0.55^{\circ}$ \\
\hline & S & $-0.45^{\circ}$ \\
\hline \multirow[t]{2}{*}{ CFUs Dens } & W & -0.50 \\
\hline & $\mathrm{S}$ & -0.40 \\
\hline \multirow[t]{2}{*}{ CFUs- $\mathrm{NO}_{3}$} & W & $0.84^{\cdots}$ \\
\hline & $\mathrm{S}$ & 0.42 \\
\hline \multirow[t]{2}{*}{ CFUs- $\mathrm{NH}_{4}$} & W & 0.27 \\
\hline & $S$ & 0.20 \\
\hline \multirow[t]{2}{*}{ CFUs-Si $\left(\mathrm{OH}_{4}\right)$} & $W$ & $0.59^{\circ}$ \\
\hline & $\mathrm{S}$ & 0.43 \\
\hline \multirow[t]{2}{*}{ CFUs-Cyan } & W & $-0.84 \cdots$ \\
\hline & $\mathrm{S}$ & 0.09 \\
\hline \multirow[t]{2}{*}{ CFUs-TC } & W & 0.17 \\
\hline & $\mathrm{S}$ & -0.22 \\
\hline No of & w & $\mathrm{n}=14$ \\
\hline samples & $\mathrm{S}$ & $\mathrm{n}=20$ \\
\hline
\end{tabular}


A significant positive correlation between CFUs and Qr4 was found in the surface layer during both the winter and summer periods (Table 2). A positive correlation was also observed between CFUs and nitrate and silicate but only during winter. Conversely, there was negative correlation with salinity in winter and summer, with upwelling in summer, and cyanobacteria in winter (Table 2).

\section{DISCUSSION}

\section{Physical and biological control of bacterioplankton population}

Variability in bacterial number is a typical feature for most marine coastal habitats. In the Ría de Vigo which opens wide to the Atlantic Ocean, the coefficient of variation ranged from $34 \%$ in the middle layer to $56.3 \%$ at the surface. This variability was similar to that found in other very different ecosystems, for example the brackish waters of the Kiel Bight in the western Baltic Sea (Zimmermann 1977), where water exchange is severely hampered by narrow and shallow straits, or in the deep but strongly mixed cold waters of Admiralty Bay in West Antarctica (Donachie 1995).

When calculated on the basis of mean winter and mean summer values, the summer bacterioplankton (TC) population at the surface was on average numerically larger than the winter population. Nevertheless, when TC fluctuations at the surface are considered over a short period of time ( 3 to $4 \mathrm{~d}$, on the basis of biweekly measurements) counts changed much more dramatically, e.g. by a factor of ca 6 in April, or 3 in August (Fig. 3a). This means that the general trend in seasonal terms (winter-summer transition) is for TC to increase, although there are short-term fluctuations during this time. Similar situations, although with smaller ranges, were noted in the middle and bottom layers.

The water column's physical structure was shown to have considerable influence on bacterioplankton populations in the photic layer. Thus, during winter and in spite of the high run-off associated with strong downwelling in January (Fig. 4a, c, d), the correlation between $\mathrm{TC}$ at the surface and $\mathrm{TC}$ in the middle layer was positive and significant ( $r=0.62, p<0.001, n=30$ ), even though mean $\mathrm{TC}$ values were 1.2 times higher at the surface (Fig. 3a, b). On the contrary, during the summer period there was no significant correlation between $\mathrm{TC}$ at the surface and in middle layer. These facts suggest that winter bacterioplankton communities from the surface and middle layers were not totally separated by a discontinuity (thermoclines or halo- clines) that could prevent mixing. During summer, however, both layers were apparently separated by such a discontinuity based on thermal stratification (Fig. $4 \mathrm{a}, \mathrm{b}$ ). On the other hand, significant correlations between $\mathrm{TC}$ and other biological variables, such as chl $a$, cyanobacteria, and ciliates (Table 1), indicate that there exists some control by, or coupling of total bacterial numbers with, other biological components in the system.

On the basis of the multiple stepwise regression between $\log \mathrm{TC}$ and solar radiation (Qs4), temperature (Temp), upwelling (Upw4), run-off (Qr4), and density (Dens), we can presume mechanistic connections among the physical factors and standing stock of bacteria (Tables $3 \mathrm{~A} \& 4 \mathrm{~A}$ ). In the light of these data, throughout this study, which included a strong winter to summer transition, the increasing Qs4 was the principal physical factor controlling bacterial standing

Table 3. Multiple stepwise regressions between $\log \mathrm{TC}$ and (A) physical and (B) physical and biological variables in the surface layer in Ría de Vigo ( $\operatorname{Stn} 3 \mathrm{~b}$ ). Results are presented for data collected during the full period of this study $(n=75)$, and separately for winter $(n=30)$ and summer $(n=45)$. $\beta$ : standardized coefficient of regression; $p$ : level of significance of the slopes in the regression equations. See Table 1 for abbreviations

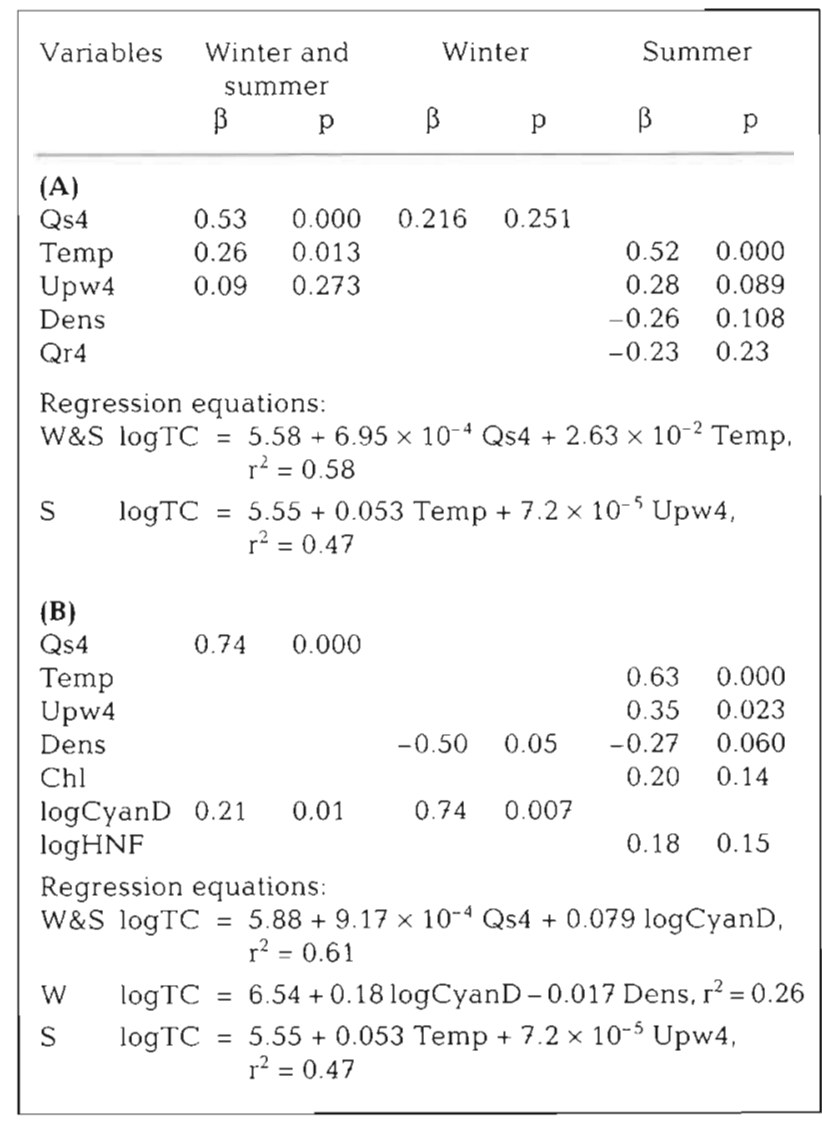


Table 4. Multiple stepwise regressions between $\log \mathrm{C} C$ and (A) physical and (B) physical and biological variables in the middle layer (bottom of the photic layer) in Ría de Vigo (Stn $3 b)$. Results are presented for data collected during the full period of this study ( $n=75)$, and separately for winter $(n=30)$, and summer ( $n=45)$; $\beta$ : standardized coefficient of regression; p: level of significance of the slopes in the regression equations. See Table 1 for abbreviations

\begin{tabular}{|c|c|c|c|c|c|c|}
\hline \multirow[t]{2}{*}{ Variables } & \multicolumn{2}{|c|}{$\begin{array}{l}\text { Winter and } \\
\text { summer }\end{array}$} & \multicolumn{2}{|c|}{ Winter } & \multicolumn{2}{|c|}{ Summer } \\
\hline & $\beta$ & $p$ & $\beta$ & $\mathrm{p}$ & $\beta$ & p \\
\hline \multicolumn{7}{|l|}{ (A) } \\
\hline Qs4 & 0.46 & 0.000 & & & 0.23 & 0.177 \\
\hline Temp & 0.27 & 0.009 & & & 0.47 & 0.000 \\
\hline Qr4 & -0.32 & 0.014 & -0.33 & 0.083 & -0.39 & 0.025 \\
\hline Dens & -0.24 & 0.05 & & & -0.30 & 0.063 \\
\hline \multicolumn{7}{|c|}{$\begin{array}{l}\text { Regression equations: } \\
\begin{aligned} W \& S \log T C= & 6.57+3.6 \times 10^{-4} \text { Qs4 }+0.036 \text { Temp }-0.002 \\
& \text { Qr4 }-0.04 \text { Dens, } r^{2}=0.37\end{aligned}\end{array}$} \\
\hline S $\quad \log 7$ & \multicolumn{6}{|c|}{$\log \mathrm{TC}=5.03+0.087 \mathrm{Temp}-0.0039 \mathrm{Qr4}, \mathrm{r}^{2}=0.37$} \\
\hline Chl & 0.55 & 0.000 & 0.40 & 0.036 & 0.45 & 0.001 \\
\hline logrcyan & 029 & 0.019 & 0.44 & 0.025 & & \\
\hline Temp & 0.22 & 0.028 & & & 0.39 & 0.003 \\
\hline $\log \mathrm{Cil}$ & & & -0.27 & 0.15 & 0.29 & 0.03 \\
\hline Qs4 & 0.38 & 0.001 & & & & \\
\hline \multicolumn{7}{|c|}{$\begin{array}{l}\text { Regression equations: } \\
\begin{aligned} \mathrm{W} \& \mathrm{~S} \log \mathrm{TC}= & 5.48+0.017 \mathrm{Chl}+2.98 \times 10^{-4} \mathrm{Qs} 4+ \\
& 0.064 \log \text { Cyan }+0.029 \mathrm{Temp}, \mathrm{r}^{2}=0.54\end{aligned}\end{array}$} \\
\hline $\log \mathrm{T}$ & $\begin{aligned} C= & 5 . \\
& \end{aligned}$ & $\begin{array}{l}38+0.1 \\
.068 \log \end{array}$ & $\begin{array}{l}\log C y a \\
\mathrm{Cil}_{1} \mathrm{r}^{2}=\end{array}$ & $\begin{array}{l}n+0.08 \\
0.40\end{array}$ & $4 \mathrm{Chl}$ & \\
\hline $\log$ & $\begin{aligned} C & =5 . \\
& +\end{aligned}$ & $\begin{array}{l}10+0.01 \\
0.068100\end{array}$ & $\begin{array}{l}3 \mathrm{Chl}+ \\
\mathrm{Cil}, \mathrm{r}^{2}=\end{array}$ & $\begin{array}{l}0.069 \mathrm{Te} \\
0.56\end{array}$ & & \\
\hline
\end{tabular}

stock, not only at the surface (Table 3A), but also in the middle layer (Table 4A), with some negative influence from run-off and high density water on total bacteria counts in the middle layer (Table 4A). After the transition to summer, the period of regular high solar radiation, the correlation between Qs4 and TC disappeared (surface layer) or lost its high significance (middle layer), and temperature became the main factor controlling bacterial population. It should also be noted that $\log \mathrm{TC}$ was slightly but still positively related to upwelling during summer in the surface layer, and negatively related to run-off and density in the middle layer.

When all biological variables were added to the multiple regression analysis, the general pattern of relations between $\log \mathrm{TC}$ and physical factors in the surface layer did not differ appreciably from that described above. The weak relationships between $\log \mathrm{TC}$ and chl a (Chl), dividing cyanobacteria (CyanD) or heterotrophic nanoflagellates (HNF) which did appear were well below the level of significance in summer, only being relatively important for CyanD in winter (Table 3B). In the middle layer, however, biological factors (Chl and Cyan) appeared to be statistically significant throughout the study at the same time that Qs4 and temperature remained important (Table 4B). During summer, cyanobacteria and Qs4 were replaced by ciliates. Moreover, in this middle layer, determination coefficients $\left(r^{2}\right)$ increased considerably when biological variables were added and analysed in tandem with physical variables, whereas in the surface layer (with the exception of winter period, with very low $r^{2}$ ), they were similar in both cases, i.e. with or without biological variables. This fact seems to derive from the varying reactions of heterotrophic bacteria in habitats under different levels of stress from physical factors such as solar radiation, temperature, run-off, upwelling, etc.

It can be concluded that the surface layer was more controlled by physical factors, whereas in the middle layer (bottom of the photic zone) biological factors played a role at least similar to that of physical factors. Solar radiation and water temperature promote bacterial growth, while run-off and strong coastal upwelling (as reflected through density influence) dilute the bacterial population in the ría. A slight positive influence of coastal upwelling on the surface bacterial population can be derived from regression equations (Table 3), probably through both promoting phytoplankton growth and bringing nutrients to the surface layer during summer.

The nature of the strong positive correlation between heretotrophic bacteria and Qs4 is undoubtedly related to increases in phytoplanktonic primary production (cf. highly significant correlation between Chl a and Qs4; $r=0.56, p<0.001, n=74$ ), of which ca 30 to $50 \%$ is utilised by heterotrophic bacteria in the marine environment (Williams 1981, Azam et al. 1983, Ducklow 1983, Hagstrom 1984). Another factor that may be acting in the ecosystem and which can be invoked to partially explain the correlation between $\log T C$ and Qs4 is ultraviolet (UV) radiation. Photolysis by UV-B in sunlight of fluvially derived humic substances (which are rather resistant to microbial breakdown) produces substances such as pyruvate, acetaldehyde, formaldehyde and glyoxylate, which are easily broken down or assimilated by bacteria (Mopper \& Zhou 1990). The rate of formation of low molecular weight breakdown products is directly proportional to light intensity at $300 \mathrm{~nm}$ and to the concentration of humus; in lakes, this ranges from 7 to $22 \mathrm{mg} \mathrm{C} \mathrm{m}{ }^{-2} \mathrm{~d}^{-1}$ (de Haan 1993). Moreover, there are indications that in seas and oceans, photolysis of carbon fixed by phytoplankton is greater ( 5 to $40 \%$ ) than the photolysis of humus (Laane et al. 1985). 
The availability of large quantities of bacterial biomass as a source of food in pelagic habitats is restricted, above all, to other ecologically important and diverse microbial groups, such as protozooplankton (Wright \& Coffin 1984). Important questions remain, however, insofar as how observed relationships between bacteria and protozoan standing stocks can testify to predator-prey dependence in terms of trophic relations. Which is more important in the control of bacterial abundance: bacterivory or losses connected more with hydrology? Gasol \& Vaqué (1993) demonstrated a weak relationship between bacterial and nanoflagellate abundance across a wide diversity of aquatic systems. This fits our findings of a lack of significant correlation between DAPI-TC and HNF (Table 1). On the other hand, the significant correlation between DAPI-TC and Cil (Table 1) seems to support their suggestion that organisms other than HNF are important predators of bacteria. A considerable body of experimental evidence indicates that ciliates, and particularly microciliates smaller than $30 \mu \mathrm{m}$ (Rivier et al. 1985, Rassoulzadegan \& Sheldon 1986), constitute a link between dissolved organic carbon, bacteria, and higher trophic levels in aquatic food chains

\section{Run-off, upwelling and spore-forming bacteria}

Aerobic spore-forming bacteria (CFUs) can be passively transported through streams or groundwater to areas in which they can grow. During studies in Antarctica, Zdanowski (1995) found that ca $12.8 \%$ of saprophytic bacteria in a glacial stream infiltrating soil and running into Admiralty Bay were halotolerant. Such translocation from soil to the Ría de Vigo can occur during run-off into the drainage basin. Despite their low numbers, the presence of viable spores, especially during periods of high run-off, support the alien status in seawater of this (CFUs) bacterial fraction.

The patterns of correlation between CFUs and physical variables in the surface layer revealed by both simple (Table 2) and multiple stepwise (Table 5) regression differ distinctly to those for TC (Tables $1,3 \& 4$ ). Amongst others, the most prominent contrasts, i.e. positive correlation of CFUs with Qr4 but negative with upwelling and temperature versus negative correlation of TC with Qr4 but positive with upwelling and temperature, emphasises the existence of quite distinct mechanisms driving the development of both bacterial populations.

The highest CFU numbers, recorded in July in the surface layer, should be regarded with special interest as they occurred when all primary and secondary production is usually driven by upwelling. At this time
Table 5. Multiple stepwise regressions between logCFU (spore-forming aerobic bacteria) and Qs4, Temp, Upw, Qr4. and Dens in the surface layer in Ría de Vigo (Stn 3b). Results are presented for data collected during the full period of this study $(n=34)$, and separately for winter $(n=14)$ and summer $(n=20) ; \beta$ : standardized coefficient of regression; $p$ : level of significance of the slopes in the regression equations. See Table 1 for abbreviations

\begin{tabular}{|c|c|c|c|c|c|c|}
\hline \multirow[t]{2}{*}{ Variables } & \multicolumn{2}{|c|}{$\begin{array}{l}\text { Winter and } \\
\text { summer }\end{array}$} & \multicolumn{2}{|c|}{ Winter } & \multicolumn{2}{|c|}{ Summer } \\
\hline & $\beta$ & $\mathrm{p}$ & $\beta$ & $p$ & $\beta$ & $\mathrm{p}$ \\
\hline Upw 4 & -0.55 & 0.001 & -0.35 & 0.129 & -0.61 & 0.018 \\
\hline Temp & -0.47 & 0.012 & -0.59 & 0.016 & & \\
\hline Qr4 & 0.39 & 0.024 & 0.62 & 0.014 & 0.51 & 0.052 \\
\hline Qs4 & 0.37 & 0.076 & & & & \\
\hline Dens & & & & & 0.38 & 0.104 \\
\hline \multicolumn{7}{|c|}{$\begin{aligned} \text { W\&S logCFU }= & 0.82-2.8 \times 10^{-4} \text { Upw4-0.077 Temp }+6.3 \\
& \times 10^{-3} \text { Qr } 4+0.7 \times 10^{-3} \mathrm{Qs}_{1}, \mathrm{r}^{2}=0.56\end{aligned}$} \\
\hline $\log C$ & $\log \mathrm{CFU}=$ & \multicolumn{5}{|c|}{$\begin{array}{l}1.12+6.4 \times 10^{-3} \text { Qr4 }-0.089 \text { Temp }-1.4 \times \\
10^{-4} \mathrm{Upw} 4, \mathrm{r}^{2}=0.66\end{array}$} \\
\hline \multicolumn{2}{|c|}{$\log \mathrm{CFU}=$} & \multicolumn{5}{|c|}{$\begin{array}{l}-3.03-3.7 \times 10^{-4} \text { Upw } 4+0.016 \text { Qr4 }+ \\
0.12 \text { Dens, } r^{2}=0.65\end{array}$} \\
\hline
\end{tabular}

there is also the greatest bacterial production in the soil, so terrestrial run-off into the drainage basin can inoculate surface waters of the Ria de Vigo with larger numbers of spore-forming bacteria than during the winter.

These findings throw light on the considerable impact of terrestrial run-off in supplying and coastal upwelling in diluting the Ría de Vigo with such a fraction of bacteria as important as the spore formers. We base our hypothesis regarding the potential importance of this fraction on the study of physiological and biochemical properties of isolates, which show extremely high ecophysiological potential (Zdanowski \& Figueiras unpubl.). It must be pointed out that in this study only the aerobic, heat-resistant spore-forming bacteria were counted. This study may indicate, however, the possibility of introduction of other bacteria, for example low-thermoresistant or strictly anaerobic spore-formers, the latter being especially important for sanitary reasons.

Acknowledgements. We thank all from the Instituto de Investigacions Mariñas who participated in the sampling. We are also very grateful to $\mathrm{A}$. M. Mosquera for her work with DAPI and ciliate counts and to Dr S. P. Donachie for his help in checking the English. This study has been supported by the European Union's MAST project, contract MAST-CT90-0017 M.K.Z. thanks 'Ministerio de Educación y Ciencia and Ministerio de Asuntos Exteriores' in Spain for all financial support and for enabling him to conduct this research in Vigo during $1990-1991$. 


\section{LITERATURE CITED}

Alexander M (1971) Microbial ecology. John Wiley \& Sons Inc, New York

Alvarez-Salgado XA, Roson G, Perez FF, Pazos Y (1993) Hydrographic variability off the Rías Baixas (NW Spain) during the upwelling season. J Geophys Res 98: $14447-14455$

Anonymous (1987) Plan de saneamiento para cinco sistemas de rías en Galicia (Ferrol, A Coruna, Arousa-Umia, Pontevedra y Vigo). In: Xunta de Galicia (ed) Documento de sintesis. Velograf SA, Santiago de Compostela, p 1-115

Azam F, Fenchel $T$, Field JG, Gray JS, Meyer-Reil LA, Thingstad $F$ (1983) The ecological role of water column microbes in the sea. Mar Ecol Prog Ser 10:257-263

Bakun A (1973) Coastal upwelling indices, west coast of North America 1946-71. NOAA Tech Rep NMFS SSRF 671 U.S. Dept. of Commerce, Seattle

Blanton JO, Tenore KR, Castillejo F, Atkinson LP, Schwing $F B$, Lavin A (1987) The relationships of upwelling to mussel production in the rias on the western coast of Spain. J Mar Res 45:497-511

Davis PG, Sieburth JMCN (1982) Differentiation of phototrophic and heterotrophic nanoplankton populations in marine waters by epifluorescence microscopy. Ann Inst Oceanogr 58:249-260

de Haan $H$ (1993) Solar UV-light penetration and pho-

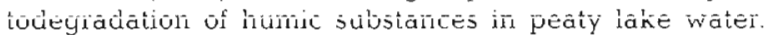
Limnol Oceanogr 38:1072-1076

Dietrich G, Kalle K, Krauss W, Siedler G (1980) General oceanography. An introduction, 2nd edn. J Wiley \& Sons, New York

Donachie SP (1995) Ecophysiological description of marine bacteria from Admiralty Bay (Antarctica), and the digestive tracts of selected Euphausiidae. In: RakusaSuszczewski S, Donachie SP (eds) Microbiology of Antarctic marine environments and krill intestine, its decomposition and digestive enzymes. Department of Antarctic Biology, Polish Academy of Sciences, Warsaw, p 101-196

Ducklow HW (1983) Production and fate of bacteria in the oceans. BioSci 33:494-501

Fenchel T, Hemmingsen BB (1974) Manual of microbial ecology. Akademisk Forlag

Fierro GS, Banda IG, Masso JM (1976a) Análisis Bacteriológico en las Rías de Arosa, Vigo y Pontevedra. Bol Inst Esp Oceanogr 205:5-1.3

Fierro GS, Banda IG, Seco MPM, Chereguini MO (1976b) Contribución al estudio de las especies de bacterias marinas. Bol Inst Esp Oceanogr 214:3-17

Figueiras FG, Jones KJ, Mosquera AM, Alvarez-Salgado XA, Edwards A, MacDougall N (1994) Red tide assemblage formation in an estuarine upwelling ecosystem: Ría de Vigo. J Plankton Res 16:857-878

Fraga F, Margalef R (1979) Las rias gallegas. In: Estudio y explotación del mar en Galicia. Cursos y congresos, University of Santiago, Santiago, p 101-121

Fuhrman JA, MCManus GB (1984) Do bacteria-sized marine eucaryotes consume significant bacterial production? Science 224:1257-1260

Garrison DL, Gowing MM (1993) Protozooplankton. In: Friedmann El (ed) Antarctic microbiology. Wiley-Liss, Inc, New York, p 123-165

Gasol JM, Vaque D (1993) Lack of coupling between heterotrophic nanoflagellates and bacteria: a general phenomenon across aquatic systems? Limnol Oceanogr 38 $657-665$
Grasshoff $\mathrm{K}$, Johannsen $\mathrm{H}$ (1972) A new sensitive and direct method for the automatic determination of ammonia in seawater. J Cons Int Explor Mer 34:516-521

Hagstrom A (1984) Aquatic bacteria: measurements and significance of growth. In: Klug MG, Reddy CA (eds) Current perspectives in microbial ecology. American Society for Microbiology, Washington, DC, p 495-501

Hansen HP, Grasshoff $K$ (1983) Automated chemical analy-

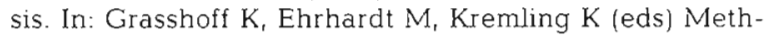
ods of seawater analysis. Verlag Chemie, Weinheim, p 347-379

Hanson RB, Alvarez-Ossorio MT, Cal R, Campos MJ, Roman M. Santiago G, Varela M. Yoder JA (1986) Plankton response following a spring upwelling event in the Ría de Arosa, Spain. Mar Ecol Prog Ser 32:101-113

Karl DM, Knauer GA (1984) Detritus-microbe interactions in the marine pelagic environment: selected results from the vertex experiment. Bull Mar Sci 35:550-565

Laane RWPM, Gieskes WWC, Kraay GW, Eversdijk A (1985) Oxygen consumption from natural waters by photo-oxidizing processes. Neth J Sea Res 19:125-128

Mopper K, Zhou X (1990) Hydroxyl radical photoproduction in the sea and its potential inpact on matine processes. Science 250:661-664

Morita RY (1984) Substrate capture by marine heterotrophic bacteria in low nutrient waters In: Hobbie IE, Williams PJLeB (eds) Heterotrophic activity in the sea. Plenum ríess, rvew Y'ún, p $83-100$

Mouriño C, Fraga F (1985) Determinación de nitratos en agua de mar. Invest Pesq 49:81-96

Porter KG, Feig YS (1980) The use of DAPI for identifying and counting aquatic microflora. Limnol Oceanogr 25:943-948

Prego R (1990) Las sales nutrientes en las rías gallegas. Inf Tec Sci Mar 157:1-33

Prego R, Fraga F (1992) A simple model to calculate the residual flows in a Spanish ría. Hydrographic consequences in the Ria of Vigo. Estuar Coast Shelf Sci 34:603-615

Prego R, Fraga F, Rios AF (1990) Water interchange between the Ría of Vigo and the coastal shelf. Sci Mar 54 $95-100$

Rassoulzadegan F, Sheldon RW (1986) Predator-prey interactions of nanozooplankton and bacteria in an oligotrophic marine environment. Limnol Oceanogr 31:1010-1021

Rios AF, Nombela MA, Perez FF, Rosón G, Fraga F (1992) Calculation of runoff to an estuary. Ría de Vigo. Sci Mar 56 $29-33$

Rivier A, Brownlee R, Sheldon W, Rassoulzadegan F (1985) Growth of microzooplankton: a comparative study of bactivorous zooflagellates and ciliates. Mar Microb Food Webs 1:51-60

Rosón G, Pérez FF, Alvarez-Salgado XA, Figueiras FG (1995) Variation of both thermohaline and chemical properties in an estuarine upwelling ecosystem: Ría de Arousa. I. Time evolution. Estuar Coast Shelf Sci 41:195-213

Tenore RK and 18 others (1995). Fisheries and oceanography off Galicia, NW Spain: mesoscale spatial and temporal changes in physical processes and resultant patterns of biological productivity. J Geophys Res 100:10943-10966

Williams PJLeB (1981) Incorporation of microheterotrophic processes into the classical paradigm of the planktonic food web. Kiel Meeresforsch 5:1-28

Wright RT, Coffin RB (1984) Measuring microzooplankton grazing on planktonic marine bacteria by its impact on bacterial production. Microb Ecol 10:137-149

Yentsch CS, Menzel DW (1963) A method for the determination of phytoplankton chlorophyll and phaeophytin by fluorescence. Deep Sea Res 10:221-231 
Zdanowski MK (1988) Matter conversion in the course of krill (Euphausia superba Dana) decomposition in the Antarctic ecosystem. Part 1. Pol Arch Hydrobiol 35: $65-96$

Zdanowski MK (1995) Characteristics of bacteria in selected Antarctic marine habitats In: Rakusa-Suszczewski S, Donachie SP (eds) Microbiology of Antarctic inarine environments and krill intestine, its decomposition and digestive enzymes. Department of Antarc-

This article was submitted to the editor tic Biology, Polish Academy of Sciences, Warsaw, p $7-100$

Zimmermann R (1977) Estimation of bacterial number and biomass by epifluorescence microscopy and scanning electron microscopy. In: Rheinheimer G (ed) Microbial ecology of brackish water environment. Springer-Verlag, Berlin, p 103-120

ZoBell CE (1941) Studies on marine bacteria. 1. The cultural requirements of heterotrophic aerobes. J Mar Res 4:42-75

Manuscript first received: July 8, 1996

Revised version accepted: January 15, 1997 